\title{
Sporothrix eucalypti, UM NOVO PATÓGENO DO EUCALIPTO NO BRASIL
}

\author{
ACELINO C. ALFENAS ${ }^{1}$, EDIVAL A.V. ZAUZA ${ }^{1}$, OSMAR P.P. ROSA ${ }^{2}$ \& TEOTÔNIO F.ASSIS ${ }^{3}$
}

${ }^{1}$ Universidade Federal de Viçosa, Dep. de Fitopatologia, Viçosa-MG, e-mail: aalfenas@mail.ufv.br; ${ }^{2}$ Tecnoplanta, Barra do Ribeiro-RS; ${ }^{3}$ Riocell, Guaíba-RS

(Aceito para publicação em 02/02/2001)

Autor para correspondência: Acelino C. Alfenas

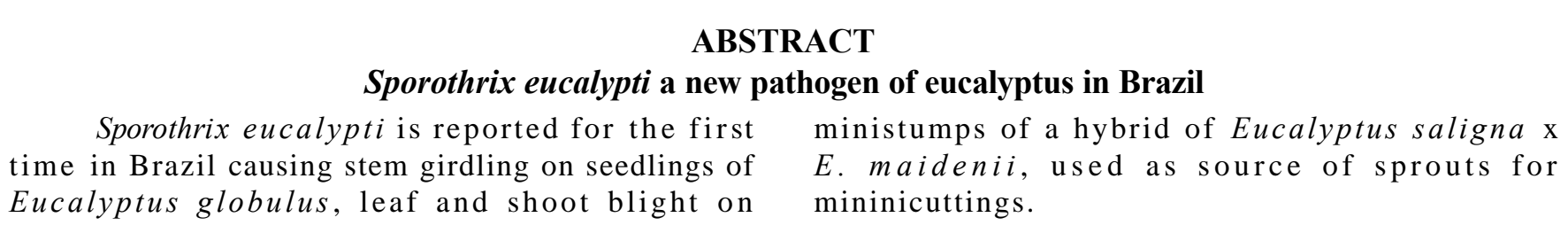

Registrou-se, em março de 2000, a ocorrência de uma nova doença de Eucalyptus sp., em minijardim clonal, na região de Barra do Ribeiro - RS. À época da inspeção, a doença encontrava-se restrita a um clone híbrido de Eucalyptus saligna Smith x E. maedenii Fmuell e, subseqüentemente, em mudas seminais de E. globulus Labill. A enfermidade, aqui designada de esporotricose do eucalipto, caracteriza-se pela infecção da haste principal de mudas (Figura 1A) e de porções apicais de brotações de minicepas produtoras de brotos para enraizamento (Figura 1B) e folhas (Figura 1C). Nas folhas, as lesões são inicialmente arroxeadas, ligeiramente arredondadas, ou de formato e dimensões variáveis. No caule e pecíolo, o patógeno induz anelamento e morte dos mesmos. Os órgãos afetados, não raro, tornam-se retorcidos e as áreas necróticas escuras recobertas com pústulas esbranquiçadas (massa de micélio, conidióforos e conídios) de um fungo, com características morfológicas típicas de Sporothrix eucalypti Wingfield, Crous \& Swart, relatado em Eucalyptus sp., na África do Sul (Wingfield et al., 1993, Mycopathologia 123:159-164). Suas colônias, em BDA, possuem odor peculiar, são brancas e esporulantes (Figura 1D); seus conídios primários (5-10 x 2,5$5 \mu \mathrm{m})$ e secundários (2,5-5 x 1,0-2,5 $\mu \mathrm{m})$ são hialinos, unicelulares, produzidos em células conidiogênicas denticuladas, hialinas e diferenciadas da hifa vegetativa (Figuras 1 E, F e G). A temperatura ótima de crescimento é 25 ${ }^{\circ} \mathrm{C}$, onde após 10 dias de incubação, no escuro, atinge uma média de $512 \mathrm{~mm}^{2}$. Para os testes de patogenicidade do fungo, 15 mudas sadias de E. globulus foram atomizadas com uma suspensão de inóculo a 2,5 x $10^{6}$ conídios/ml. Após a inoculação, as mudas foram mantidas em câmara úmida no escuro por três dias a $25^{\circ} \mathrm{C}$. Os primeiros sintomas e sinais da doença surgiram aos 14 dias da inoculação e caracterizaram-se pelo surgimento de lesões escuras, contendo esporulações branca do patógeno. A reprodução dos sintomas da doença por inoculação artificial em todas as mudas inoculadas e o reisolamento do fungo para BDA, a partir de tecidos infetados, confirmaram a etiologia da doença.

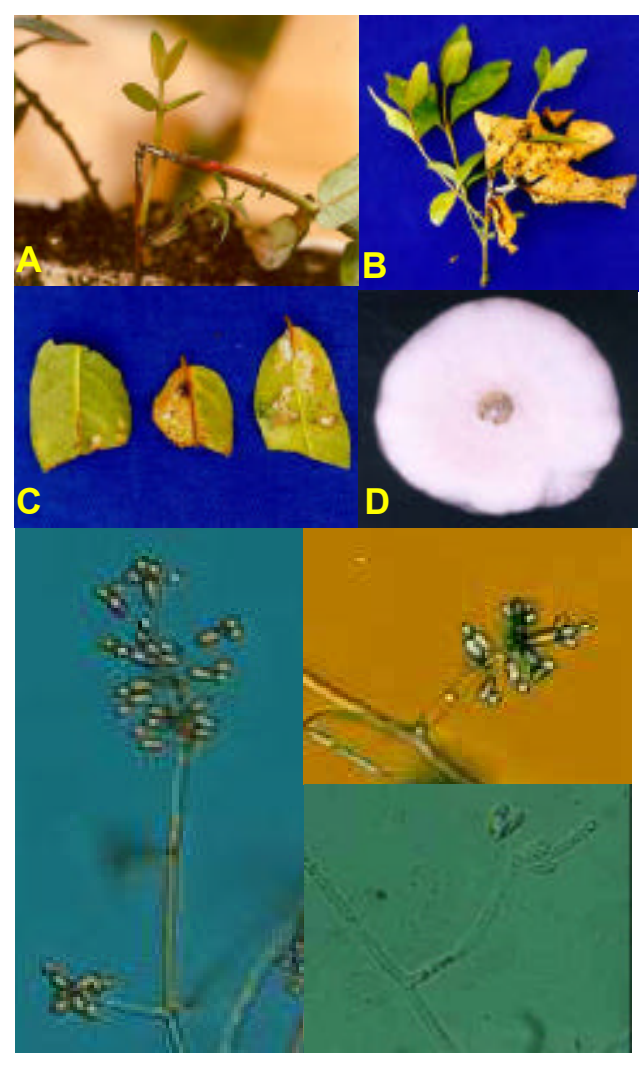

FIG. 1 - Sintomas e sinais de esporotricose do eucalipto (Eucalyptus sp.) e características morfológicas de Sporothrix eucalypti: (A) necrose e estrangulamento da haste principal de mudas de $E$. globulus; (B) anelamento e morte de porções apicais de brotações de minicepa de um clone híbrido de $E$. saligna $\times$ E. maidenii; (C) lesões em folhas, contendo esporulação branca; (D) colônia do fungo em BDA, a $25^{\circ} \mathrm{C}$; (E) conidióforos e conídios primários e secundários; ( $F$ e G) conidióforos inseridos na hifa vegetativa. Barras $=10 \mu \mathrm{m}$. 